TITLE:

\title{
Cryptoniscidae s.s. (Isopoda : Epicaridea) : Nomenclatural History and Recommendations
}

\author{
$\operatorname{AUTHOR}(\mathrm{S})$ :
}

Grygier, Mark J.

\section{CITATION:}

Grygier, Mark J.. Cryptoniscidae s.S. (Isopoda : Epicaridea) : Nomenclatural History and Recommendations. PUBLICATIONS OF THE SETO MARINE BIOLOGICAL LABORATORY 1993, 36(3): 185-195

ISSUE DATE:

1993-11-30

URL:

http://hdl.handle.net/2433/176226

RIGHT: 


\title{
Cryptoniscidae s.s. (Isopoda: Epicaridea): Nomenclatural History and Recommendations
}

\author{
Mark J. Grygier ${ }^{1)}$ \\ Seto Marine Biological Laboratory, Kyoto University, \\ Shirahama, Nishimuro, Wakayama 649-22, Japan \\ and \\ Sesoko Marine Science Center, University of the Ryukyus, \\ Sesoko, Motobu-cho, Okinawa 905-02, Japan
}

\begin{abstract}
The nomenclatural history of the parasitic isopod family Cryptoniscidac Kossmann, 1880 sensu stricto is reviewed, and irregularities are exposed and corrected. Eumetor Kossmann, 1872 and its type species E. liriopides Kossmann, 1872 are available but unrecognizable except by host. Cryptoniscus curvatus Fraisse, 1877 is designated here as the type species of Danalia Giard, 1887. Danalia lobiancoi Giard \&. Bonnier, 1890 is a nomen nudum since it was merely mentioned in a list with its host. At least five of the 12-13 available nominal species currently assigned to Danalia are nearly unrecognizable except by host. Neither Zeuxokoma Zimmer, 1927 nor Zeuxokoma Neave, 1940 qualifies as an available replacement name for the preoccupied Zeuxo Kossmann, 1872 because of lack of reference to the earlier name and lack of a type species designation, respectively. Zeuxokoma nom. nov. is proposed here as a replacement name for Zeuxo Kossmann, and Zeuxo alphei Kossmann, 1872 is designated here as the type species. The nominal subfamily Fabinae Danforth, 1970 (1963?) is unavailable because neither work involved was published in the sense of the International Code of Zoological Nomenclature. The nominal family Danaliidae Altes, 1982 includes Cryptoniscus Müller, 1864, and is thus a junior synonym of Cryptoniscidae Kossmann, 1880.
\end{abstract}

Key words: Isopoda, Cryptoniscidae, nomenclature, type species designation, replacement name

One group of epicaridean isopods are the Cryptonscina sensu Bonnier, 1900. According to different workers they constitute a single family, the Cryptoniscidae Kossmann, 1880 sensu lato, or a number of families including the Cryptoniscidae sensu stricto. This latter includes hyperparasites of rhizocephalan cirripeds, direct parasites of decapod malacostracans, and a hyperparasite of another epicaridean, and it has usually but invalidly been called Liriopsidae Bonnier, 1900. Grygier \& Bowman $(1990,1991)$ discuss the family-level nomenclature. Nine nominal genera are treated here: Liriopsis Schultze in Müller, 1859 (replacement name for preoccupied Liriope Rathke, 1843); Cryptoniscus Müller,1864; Eumetor Kossmann, 1872; Zeuxo Kossmann, 1872 (preoccupied; a replacement name is proposed here); Danalia Giard, 1887; Enthylacus Pérez, 1920; Perezina Nierstrasz \& Brender à Brandis, 1930a (replacement name for preoccupied Perezia Nierstrasz \& Brender à Brandis, 1929); Faba Nierstrasz \& Brender à Brandis, 1930b; and Heptalobus Nierstrasz \& Brender à Brandis, 1930b.

Revisions of the Liriopsidae (i.e., Cryptoniscidae s.s.) were published by Bocquet-Védrine (1974) and Altes (1982), but several nomenclatural irregularities have been passed down from earlier literature. In order to rectify this situation, this paper recounts the history of nomenclatural acts involving the Cryptoniscidae s.s.

1) Mailing address: 14804 Notley Road, Silver Spring, Maryland, 20905, U.S.A.

Publ. Seto Mar. Biol. Lab., 36(3), 185-195, $1993 . \quad$ (Article 14) 
and gives recommendations for usage, based on the International Code of Zoological Nomenclature (Code; International Commission on Zoological Nomenclature, 1985). This is not a taxonomic history; no taxonomic judgements are made and full synonymies are not presented.

\section{Genus-Level History and Nomenclatural Status of Species}

1. Liriopsis Schultze in Müller, 1859.

This genus now contains two nominal species.

Grygier \& Bowman (1990) discussed in detail the replacement of Liriope Rathke, 1843 by Liriopsis Schultze in Müller and noted that the type species is Liriope pygmaea Rathke, 1843, by monotypy.

Bonnier (1990) transferred Cryptoniscus monophthalmus Fraisse, 1877 to Liriopsis by synonymizing the two genera; this species has since remained in Liriopsis.

2. Cryptoniscus Müller, 1864.

This genus now contains two nominal species.

Grygier \& Bowman (1990) discussed the true date of publication of this genus, whereby Müller's (1871) reproposal of it as a replacement name for Liriope Rathke (now known as Liriopsis Schultze in Müller) was shown to be invalid, and they concluded that the type species is C. planarioides Müller, 1864, by monotypy.

Giard (1874) described a new species, C. larvaeformis, based on an unspecified number of female and male syntypes. He gave a brief, unillustrated description of the female and a comparison to C. planarioides, so this species is available (Code, Art. 12a).

Fraisse (1877, 1878a, 1878b) followed Müller (1871) and referred all the cryptoniscid isopods then known to Cryptoniscus rather than using the oldest available name, Liriopsis. Fraisse (1877) described three species as new, C. paguri, C. curvatus, and $C$. monophthalmus, all of which were described and illustrated in extenso and are thus available (Code, Arts. 12a, 12b(7)). Cryptoniscus paguri was based on a large number of female and larval syntypes representing many developmental stages; $C$. curvatus was based on about 20 female syntypes at various stages of metamorphosis and on numerous male and female larval syntypes; $C$. monophthalmus was based on six female syntypes, including one metamorphosing larva, and some male larval syntypes. Fraisse (1877) was a published Inaugural-Dissertation that is identical to a journal article (Fraisse, 1878a) except for the title page, first text page (no headings before the text in the dissertation), and pagination. In the dissertation the abbreviated journal title and volume and found across the tops of the plates and in small print at the bottom of p. 49, which is the first page of the fourth sheet, but not on the first pages of the other three sheets, nor on the title page. Both the dissertation and the journal have printing dates of 1877 ; the dissertation gives no other date, so its publication date must be taken as December 31, 1877 (Code, Art. 21c(ii)), but the inner title page of the bound journal volume gives the date of publication of the number in which Fraisse (1878a) appeared as January 2, 1878. 
Giard (1887) included C. larvaeformis Giard and $C$. curvatus Fraisse in his new genus Danalia (see below), where they have remained. As discussed in detail by Grygier \& Bowman (1990), Bonnier (1900) synonymized Cryptoniscus with Liriopsis. Caullery (1908) raised Cryptoniscus again from synonymy, but only for the two species C. planarioides Müller and C. paguri Fraisse. No other species have been added to Cryptoniscus since then, and C. monophthalmus Fraisse has remained in Liriopsis.

\section{Eumetor Kossmann, 1872.}

This genus now contains one nominal species.

Kossmann (1874) is a republication of Kossmann (1872); citations of this work as having appeared in 1873 (e.g., Neave, 1940) are mistaken.

Eumetor liriopides Kossmann, 1872, the type species by monotypy of Kossmann's (1872) new genus Eumetor, was based on several syntypes. Kossmann (1872) wrote that he had found three specimens in the host, but it is unclear whether he thereby meant three females or a total of three females and males (a male was illustrated); Fraisse (1878b) thought the latter. Some later authors (e.g., Pérez, 1920; Altes, 1982) have considered this genus and species to be nomina nuda because the animal is unrecognizable; however, Kossmann (1872) distinguished both sexes of E. liriopides from Liriope (i.e., Liriopsis) by morphological features and illustrated the male, so the name is available under the Code (Arts. 12a, 12b(7)). Von Martens (1875) suggested an unjustified emendation of the specific name, "liriopi[oi]des".

4. Zeuxo Kossmann, 1872.

This genus, being an unreplaced junior homonym, now validly contains no nominal species.

Kossmann's (1872) second new genus, Zeuxo, was proposed for his two new species, but neither was designated the type species by him or any subsequent author. Zeuxo porcellanae Kossmann, 1872, described first, was based on two female syntypes that differed somewhat from each other in form, and Z. alphei Kossmann, 1872 was based only on the female holotype. Both specific names are available because brief descriptions accompanied by illustrations were offered (Code, Arts. 12a, $12 b(7))$.

Fraisse (1878b) transferred $Z$. porcellanae to Cryptoniscus, leaving only $Z$. alphei in Zeuxo. However, he did not explicitly designate a type species for Zeuxo, and there is no valid procedure of type designation merely by elimination (Code, Art. 69b).

Kossmann (1880) described a third species of Zeuxo, Z. longicollis, based on three female syntypes. The description was very brief, but characters distinguishing this species from two others were offered, as well as illustrations; therefore, $Z$. longicollis is available (Code, Arts. 12a, 12b(7)). Kossmann (1880) also transferred Cryptoniscus larvaeformis Giard and C. curvatus Fraisse to Zeuxo. All three just-mentioned species were later included by Giard (1887) in his new genus Danalia (see below), where they have remained.

Kossmann (1884) later acknowledged that Zeuxo Kossmann, 1872 was preoccupied by the tanaidacean Zeuxo Templeton, 1840 , but did not suggest a replacement name 
and still did not designate a type species for his genus Zeuxo. Giard (1887) and Bonnier (1900) considered it likely that the two original species of Zeuxo should be assigned to two different genera, but took no formal action.

Caullery (1908) knew that Zeuxo Kossmann, 1872 was preoccupied and on that basis correctly disregarded its priority over Danalia Giard, 1887 in synonymizing the two genera, but he also did not suggest a replacement name. "Danalia (Zeuxo) porcellanae" and "Danalia (Zeuxo) alphei" were include in Wimpenny's (1927) list of the species of Liriopsidae (i.e., Cryptoniscidae s.s.). As with a similar treatment by Altes (1982), this should not be interpreted as a designation of Zeuxo as a subgenus of Danalia, but a simple statement of synonymy following Caullery (1908). Altes (1982) assigned one of Kossmann's (1872) original species of Zeuxo to Danalia (as "D. (Zeuxo) porcellanae") and the other provisionally to Faba Nierstrasz \& Brender à Brandis (see below; misspelled as " $F$. alphaei").

In a list of the genera of the Cryptoniscidae s.l., Zimmer (1927) included "Zeuxokoma Kossmann" without citing a date, but Kossmann seems never to have proposed this name himself. Zimmer (1927) made no reference to the earlier name Zeuxo Kossmann; while the Code does not explicitly require this, logically it seems impossible to designate a replacement name without mentioning the name that is being replaced. Zeuxokoma Zimmer cannot be regarded as an emendation, for in that case explicit reference to the prior name is required (Code, Art. 33b(i)); it is evidently just an unavailable, incorrect subsequent spelling of Zeuxo (Code, Art. 33c).

Neave's (1940) entry for Zeuxo Kossmann directs one to "see Zeuxokoma Zimmer 1927", and the latter entry reads, "Zeuxokoma (n.n. pro Zeuxo Kossmann 1873) Kossmann (teste Zimmer 1927...)". Since Zimmer (1927) did not make a valid replacement and Neave (1940) read much more into Zimmer's list than was actually there, the correct attribution of the replacement name would be Zeuxokoma Neave, 1940. However, every generic name proposed after 1930, even as a replacement name, must have a type species in order to be available (Code, Art. 13b). Zeuxo Kossmann and Zeuxokoma Neave had no designated type species, so the latter was unavailable.

5. Danalia Giard, 1887.

This genus now contains 13-14 nominal species, depending on whether Zeuxo alphei Kossmann, 1872 is assigned to it.

Giard (1887) proposed this genus for five nominal species of hyperparasites of Sacculina without designating a type species. These included the three previously described species, D. larvaeformis (Giard, 1874; originally in Cryptoniscus), D. curvata (Fraisse, 1877; originally in Cryptoniscus), and D. longicollis (Kossmann, 1880; originally in Zeuxo), and Giard's two new species. Danalia Dohrnii Giard, 1887 (corrected spelling: D. dohrnii) was based on three young female syntypes that had been identified preliminarily as Cryptoniscus curvatus in an Appendix by Fraisse $(1877,1878 \mathrm{a})$ but which were from a different host species than Fraisse's other specimens of that species. Giard (1887) distinguished $D$. dohrnii only by the host but he also referred to Fraisse's (1877, 1878a) illustration of the three specimens in situ on their host, which constitutes an indication (Code, Art. 12c), so the specific name is available. Danalia pellucida 
Giard, 1887 was distinguished from the original two species of Zeuxo, and from the species then assigned to Cryptoniscus that were known to parasitize Peltogaster, on the basis of the morphology of the attachment organ; therefore, it is available (Code, Art. 12a), although it may no longer be recognizable solely on that basis. No subsequent authors have designated a type species for Danalia.

Danalia Lo Biancoi (corrected spelling: D. lobiancoi) was first proposed by Giard \& Bonnier (1890), but it is concluded to be a nomen nudum because the only information provided about it concerned the host and locality, neither of which constitutes an indication (Code, Art. 12c). Giard \& Bonnier (1890) also cited an earlier worker in connection with this species, Salvatore Lo Bianco, but not the specific work by Lo Bianco nor its date; such ambiguity cannot qualify as an indication by bibliographic reference (Code, Arts. 12b(1), 12b(7)). While D. lobiancoi has subsequently appeared in several lists (e.g., Bonnier, 1900; Wimpenny, 1927; Altes, 1982), no new descriptive information about it has appeared and it remains a nomen nudum.

Smith (1906) proposed a new species, D. ypsilon, with no description but only a poor illustration of a female in situ on its host. The drawing nonetheless constitutes an indication (Code, Art. $12 b(7)$ ), so his scientific name was made available already in 1906, not by Wimpenny's (1927) redescription of this species.

Caullery (1908) transferred Kossmann's (1872) two original species of Zeuxo $(Z$. porcellanae and $Z$. alphei) to Danalia and also proposed a new species, D. gregaria, which was not illustrated and was based on 11 female and eight male syntypes. Aside from a unique host, two provisional distinctions from $D$. curvatus (Fraisse) were mentioned: occurrence on a single host crab (p. 593: “ ... cet état grégaire peut tres bien être un charactère spécifique.") and male behavior (p. 593: "Le fait que des mâles s'insinuent sous la cuticule ... est peut-être aussi l'indice d'une différence spécifique."). While $D$. gregaria is very nearly a nomen nudum, I am interpreting these provisional distinctions as a diagnosis which makes the specific name available (Code, Arts. 12a, 15).

Several other species of Danalia were subsequently proposed; all included descriptions and illustrations and so are available (Code, Art. 12a). Nierstrasz \& Brender à Brandis (1923) proposed a new species, D. caulleryi, which was diagnosed only by its host; a short description of the only specimen, the damaged female holotype, was presented together with a drawing and photographs. Nierstrasz \& Brender à Brandis (1925) described another new species, D. fraissei, based on two syntypes, a female and a male, and both sexes were illustrated. Harant (1925) described a new species, D. inopinata, based on a female, the holotype, with a full description and figure. Fize (1955) proposed a new species, D. hapalocarcini, in a preliminary illustrated report based on an unspecified number of female, male, and larval syntypes; she included a list of purportedly diagnostic features in her discussion, so her scientific name was made available already in 1955 (Gode, Art. 12a), not by Fize's (1956) more detailed redescription of the species.

List of nominal species of Danalia Giard, 1887, and their nomenclatural and taxonomic status. D. porcellanae (Kossmann, 1872) — available, poorly known. 
D. alphei (Kossmann, 1872) - available, poorly known, assignment to Danalia disputed, designated as the type species of Zeuxokoma nom. nov. herein.

D. laralaformis (Giard, 1874) - available, poorly known.

D. curvata (Fraisse, 1877) - available, well known, designated as the type species of Danalia herein.

D. longicollis (Kossmann, 1880) - available, poorly known.

D. dohrnii Giard, 1887 - available, defined by host.

D. pellucida Giard, 1887 - available, defined mostly by host.

D. lobiancoi Giard \& Bonnier, 1890 - nomen nudum.

D. ypsilon Smith, 1906 - available, well known.

D. gregaria Caullery, 1908 - available, defined mostly by host.

D. caulleryi Nierstrasz \& Brender à Brandis, 1923 - available, poorly known.

D. fraissei Nierstrasz \& Brender à Brandis, 1925 - available, adequately described.

D. inopinata Harant, 1925 - available, adequately described.

D. hapalocarcini Fize, 1955 - available, adequately described.

\section{Enthylacus Pérez, 1920}

This genus now contains one nominal species.

Pérez (1920) described the new genus Enthylacus, with the type species by monotypy E. trivinctus Pérez, 1920, base on numerous syntypes of both sexes, which were described and illustrated. Therefore, both the generic and specific names are available (Code, Arts. 12a, 12b(7)). Pérez considered Enthylacus to belong to the Liriopsidae sensu Bonnier (1900) (i.e., Cryptoniscidae s.s.) and suggested that Enthylacus might by synonymous with Eumetor Kossmann, 1872, which he regarded as a nomen nudum. Altes (1982) also considered Eumetor a nomen nudum and treated it provisionally as a synonym of Enthylacus. As shown above, Eumetor is actually an available name and would have priority over Enthylacus in case of synonymy.

7. Perezina Nierstrasz \& Brender à Brandis, 1930 .

This genus now contains one nominal species.

Nierstrasz \& Brender à Brandis (1929) described and illustrated the new genus Perezia, with the type species by monotypy $P$. gregaria Nierstrasz \& Brender à Brandis, 1929, based on 15 female syntypes. Because a description with illustrations was presented, their generic and specific names were available already in 1929 (Code, Arts. $12 \mathrm{a}, 12 \mathrm{~b}(7))$, but to avoid homonymy with the microsporidian Perezia Léger \& Duboscq, 1909, Nierstrasz \& Brender à Brandis (1930a) replaced their generic name by Perezina. They included this genus in the Liriopsidae sensu Bonnier (1900) (i.e., Gryptoniscidae s.s.), close to Enthylacus Pérez.

8. Faba Nierstrasz \& Brender à Brandis, 1930.

This genus now contains two or three nominal species, depending on whether Zeuxo alphei Kossmann, 1872 is included.

Nierstrasz \& Brender à Brandis (1930b) proposed the new genus Faba, with their two new species, and they compared Faba to Danalia Giard without assigning Faba to any of Bonnier's (1900) families. Faba setosa Nierstrasz \& Brender à Brandis, 1930, the type species by original designation, and F. glabra Nierstrasz \& Brender à Brandis, 1930 were each based on one female holotype. Both species were described and illustrated and are thus available (Code, Arts. 12a, 12b(7)). 
The supposed rhizocephalan Thompsonia luetzeni Høeg \& Bruce, 1988, based on two "externae" (the holotype and the paratype), is evidently really an isopod related to Faba (Høeg \& Rybakov, 1992); T. luetzeni was diagnosed and is thus available (Code, Art. 13a(i)).

9. Heptalobus Nierstrasz \& Brender à Brandis, 1930.

This genus now contains one nominal species.

Nierstrasz \& Brender à Brandis (1930b) proposed another new genus, Heptalobus, with the type species by monotypy $H$. paradoxus Nierstrasz \& Brender à Brandis, 1930b. It was based on two non-identical females (the holotype and the paratype) parasitizing two different species of the shrimp Spirontocaris, which is the same host genus as that of Faba setosa Nierstrasz \& Brender à Brandis. Heptalobus paradoxus was described and illustrated and is thus available (Code, Arts. 12a, 12b(7)). Neither the original authors nor any others besides Danforth (1963, 1970; see below) have tried to place it systematically.

\section{Family-Level History}

Grygier \& Bowman (1990) discussed in detail why the family name Liriopsidae Bonnier, 1900 cannot be applied to any family-level taxon which includes the genus Cryptoniscus Fraisse and why Cryptoniscidae Kossmann, 1880 is the valid name for such a taxon. Bonnier's (1900) concept of the family included Liriopsis Schultze in Müller (with Cryptoniscus Müller as a synonym), Danalia Giard, Eumetor Kossmann, and Zeuxo Kossmann. As noted above, Cryptoniscus was resurrected by Caullery (1908), and the genera Enthylacus Pérez and Perezina Nierstrasz \& Brender à Brandis were added to the concept of the family by their respective authors. Caroli (1953) proposed on morphological grounds to transfer these last two genera to a related family, the Cabiropsidae Bonnier, 1900 (corrected spelling Cabiropidae; see Sassaman, 1992), but Nielsen \& Strömberg (1965) retained Enthylacus and Perezina in the Liriopsidae.

Danforth (1970) treated the Gryptoniscidae s.l. as a family. His actions pertinent to the present topic included the synonymization of Zeuxo with Danalia in the subfamily Liriopsinae (i.e., valid name Cryptoniscinae) and the proposal of a new subfamily, Fabinae, for Faba Nierstrasz \& Brender à Brandis and Heptalobus Nierstrasz \& Brender à Brandis. Danforth's (1963) dissertation (not seen) and Danforth (1970) are not published in the sense of the Code (Art. 8c) since they were only distributed as reproductions from microfilm; therefore, the taxonomic actions proposed therein have no formal standing in nomenclature, and Fabinae Danforth is not an available name.

Bocquet-Védrine (1974) expanded the concept of the family Liriopsidae Bonnier (i.e., valid name Cryptoniscidae) by the inclusion of two subfamilies, Liriopsinae Bonnier, 1900 (i.e., valid name Cryptoniscinae) and Crinoniscinae Bonnier, 1900 (not discussed here). She included within Liriopsinae only three genera that, in her opinion, had had their validity established, Liriopsis, Cryptoniscus, and Danalia. 
Altes' (1982) revision of the Liriopsidae (i.e., Cryptoniscidae s.s.) did not cite Bocquet-Védrine (1974) and did not discuss Perezina and Heptalobus. He split the family into two families: Liriopsidae for Liriopsis and Enthylacus, and Danaliidae Altes, 1982 for Danalia, Cryptoniscus, and, provisionally, Faba. Because Cryptoniscus was included, the nomenclaturally valid name for Danaliidae sensu Altes is Cryptoniscidae Kossmann (see Grygier \& Bowman, 1990); however, Liriopsidae Bonnier, 1900 is indeed the available name which is valid for the other family.

Wägele $(1987,1989)$ proposed a radical reclassification of the Isopoda. In his system the two families recognized by Altes (1982) were demoted with their content unchanged to the level of the two tribes (Liriopsini and Danaliini) of the subfamily Liriopsinae within the family Bopyridae. Wägele (1987) mistakenly attributed Liriopsini to Altes $(1981(s i c)$ ), but in Wägele (1989) he corrected the attribution, to Bonnier (1900). For the same reason mentioned in the preceding paragraph, the correct name of Danaliini sensu Wägele $(1987,1989)$ is Cryptoniscini.

\section{Nomenclatural Recommendations}

1) No type species has yet been designated for Danalia Giard, 1887, which had five originally included nominal species. Of these, D. longicollis (Kossmann, 1880), D. larvaeformis (Giard, 1874), D. dohrnii Giard, 1887, and D. pellucida Giard, 1887 have been recorded only once and are very poorly described at best; most are probably unrecognizable except by host. Danalia curvata (Fraisse, 1877; as Cryptoniscus curvatus) benefitted from the most complete original description of the five species and is the only one of them to have undergone substantial biological study afterwards (Smith, 1906; Caullery, 1908), so I designate it as the type species of Danalia by subsequent designation (Code, Art. 69a, Recommendation 69A).

2) Danalia lobiancoi Giard \& Bonnier, 1890, is a nomen nudum. Eumetor liriopides Kossmann, 1872 and D. gregaria Caullery, 1908, like the four poorly known species originally included in Danalia (preceding paragraph), are technically available under the Code, but are so poorly described as to be essentially unrecognizable except by host. It may be possible to redescribe these species and to validate $D$. lobiancoi by collecting host crabs and rhizocephalans from the original localities; Wimpenny (1927) provides a host list. Such action will be essential before a meaningful revision of Danalia can be accomplished.

3) Zimmer (1927) and Neave (1940) failed to properly designate a replacement name for Zeuxo Kossmann, 1872 (non Templeton, 1840), and no type species has ever been designated. As an unreplaced junior homonym Zeuxo does not compete with other genera in priority (Code, Art. 23a), so authors such as Fraisse (1878b), Caullery (1908), and Altes (1982) have been free to transfer its two original species, $Z$. porcellanae and $Z$. alphei, to other genera. There has been general agreement that $Z$. porcellanae belongs to Danalia (Caullery, 1908; Wimpenny, 1927; Altes, 1982), but $Z$. alphei has been considered at least potentially generically distinct from $Z$. porcellanae (see Giard, 1887; Bonnier, 1900) and has even been assigned provisionally to Faba (see Altes, 1982). The possibility that $Z$. alphei represents a distinct genus 
cannot yet be discounted. The Faba-like "Thompsonia" luetzeni Høeg \& Bruce, 1988 may be related to this problem. Given this uncetainty about the generic-level assignment of $Z$. alphei, an available replacement name for Zeuxo Kossmann may still be necessary. I propose to so designate Zeuxokoma nom. nov., and to designate Zeuxo alphei Kossmann, 1872 as the type species by the criterion of type fixation after elimination (Code, Recommendation 69B). Contrary to popular misconception, previous appearances of a name as a nomen nudum do not prevent it from being made available for the same (or even a different) concept at a later time (Code, Glossary: nomen nudum).

5) The family-level name Fabinae Danforth, 1970 (1963?) is unavailable because the work in which it was proposed was not published in the sense of the Code.

6) If Liriopsis Schultze in Müller and Cryptoniscus Fraisse are considered to belong to different family-level taxa, as by Altes (1982) and Wägele (1987, 1989), then the valid names for the two taxa are Liriopsidae Bonnier, 1900 and Cryptoniscidae Kossmann, 1880, respectively, no matter which other genera of the Cryptoniscidae s.s. are included in either taxon. Therefore, Danaliidae Altes, 1982, which includes Cryptoniscus, is a junior synonym of Cryptoniscidae.

\section{Acknowledgments}

This work was mostly written during the tenure of a Japan Society for the Promotion of Science Postdoctoral Fellowship, under the sponsorship of E. Harada, Director, Seto Marine Biological Laboratory. The library of that Laboratory, other libraries at Kyoto University, the Natural History and Crustacean Division libraries at the National Museum of Natural History, Smithsonian Institution, and the library of the Museum of Comparative Zoology were invaluable resources. Final preparation of the manuscript was done during an appointment as Visiting Foreign Researcher, Sesoko Marine Science Center, and I thank the director, K. Yamazato. For copies of some papers and other bibliographic information, I am indebted to J.W. Wägele, J. Sieg, J. Forest, M. Llobere, J.W. Reid, N.R. Skrypzak, and Y. Yusa. I thank T. Nishikawa and two anonymous reviewers for suggestions on improving the organization of the paper.

\section{References}

Altes, J. [1981] 1982. Les Liriopsidés. Bull. Soc. Hist. Nat. Afr. Nord, 69(3+4): 3-35.

Bocquet-Védrine, J. 1974. Parenté phylogénétique des Isopodes Cryptonisciens rangés jusqu'ici dans les familles des Liriopsidae et des Crinoniscidae. In: Arvy, L. (ed.), Recherches Biologiques Contemporaines, pp. 73-78. Imp. Wagner, Nancy.

Bonnier, J. 1900. Contribution à l'étude des Épicarides: les Bopyridae. Trav. Sta. Zool. Wimereux, 8: $1-478$.

Caroli, E. 1953. Rassegna degli Epicaridei parassiti di Epicaridei finora noti, e notizia preliminare di uno nuovo (Paracabirops marsupialis n. g., n. sp.) del Golfo di Napoli. Pubbl. Staz. Zool. Napoli, 24: 84-91.

Caullery, M. 1908. Recherches sur les Liriopsidac, Épicarides Cryptonisciens parasites des Rhizocéphales. Mitt. Zool. Stat. Neapel, 18: 583-643, pl. 26.

Danforth, C.G. 1963. Bopyridian (Crustancea, Isopoda) parasites found in the eastern Pacific of the United States. Ph. D. dissertation, Oregon State University. University Microfilms, Ann Arbor, Michigan, No. 64-2353, 110 pp. (not seen).

- 1970. Epicaridea (Crustacea: Isopoda) of North America. Self-published on microfilm, Glendale, California, ii +191 pp., 48 pls.

Fize, A. 1955. Sur une espèce nouvelle de Danalia parasite d'Hapalocarcinus marsupialis Stimpson. C. R. Hebd. Séances Acad. Sci. Paris, 240(25): 2444-2447.

1956. Observations biologiques sur les Hapalocarcinidés. Contr. Inst. Océanogr. Nhatrang, 22: 
$1-30$.

Fraisse, P. 1877. Die Gattung Cryptoniscus Fr. Mueller. Inaugural-Disseration, Universität Würzburg, 58 pp., Гаaf. XII-XV.

. 1878a. Die Gattung Cryptoniscus Fr. Müller (Liriope Rathke). Arb. Zool-Zootom. Inst. Würzburg, 4(3): 239-296, Taf, XII-XV.

-1878b. Entoniscus Cavolinii n. sp., nebst Bemerkungen über die Umwandlung und Systematik der Bopyriden. Arb. Zool.-Zootom. Inst. Würzburg, 4(4): 382-440, Taf. XX-XXI.

Giard, A. 1874. Sur l'éthologie de la Sacculina Carcini. C. R. Hebd. Séances Acad. Sci., Paris, 79(4): 241-243.

- 1887. Fragments biologiques. VIII. Sur les Danalia, genre de Cryptonisciens parasites des Sacculines. Bull. Scient. Fr. Belg., (2) 18: 47-53.

\& J Bonnier. 1890. Prodrome d'une monographie des Épicarides du Golfe de Naples. Bull. Scient, Fr. Belg., (2)22: 367-391.

Grygier. M.J. \& T.E. Bowman. 1990. The correct family-level name for the "cryptoniscid" isopods (Epicaridea). Crustaceana, 58(1): 27-32.

— \& 1991. The authorship of Cryptoniscidae (Isopoda, Epicaridea); a correction. Crustaceana, 61(1): 106-107.

Harant, H. 1925. Sur un Liriopsidé nouveau. Bull. Inst. Océanogr., Monaco, 465: 1-4.

Høeg, J.T. \& A.J. Bruce. 1988. Thompsonia luetzeni, new species (Cirripedia: Rhizocephala), a solitary parasite from the alpheid shrimp Alpheus parvirostris. Bull. Mar. Sci., 42(2): 246-252.

— \& A.V. Rybakov. 1992. Revision of the Rhizocephala Akentogonida (Cirripedia), with a list of all the species and a key to the identification of families. J. Crust. Biol,, 12(4): 600-609.

International Commission on Zoological Nomenclature. 1985. International Code of Zoological Nomenclature. Third Edition. International Trust for Zoological Nomenclature in association with British Museum (Natural History), London, and University of California Press, Berkeley and Los Angeles, $\mathrm{xx}+338 \mathrm{pp}$.

Kossmann, R. 1872. Beiträge zur Anatomie der schmarotzenden Rankenfüssler. Verh. Phys.-Med. Ges. Würzburg (N.F.), 3(4): 296-335, Taf. XVI-XVIII.

. 1874. Beiträge zur Anatomie der schmarotzenden Rankenfüssler. Arb. Zool.-Zootom. Inst. Würzburg, 1: 97-137, Taf. V-VII.

- 1880. Malacostraca, (2 Theil: Anomura). Zoologische Ergebnisse einer in Auftrage der Königlichen Academie der Wissenschaften zu Berlin ausgeführten Reise in dem Küstengebiete des Rothern Mecres, Zwcite Hälfte, Erste lieferung, pp. 67-140, Taf. 4-14. Wilhelm Engelmann, Leipzig.

1884. Neuercs über Cryptonisciden. Sitzungsber. Phys.-Math. Cl. Kaiserl. Akad. Wiss. Berlin, 22: 207-223 [457-473] (each page doubly paginated).

Léger, L. \& O. Duboscq. 1909. Perezia lankesteriae, n. g. n. sp., microsporidie parasite de Lankesteria ascidiae (Ray Lank.). Arch. Zool. Exp. Gén., (5) 1: LXXXIX.

Müller, F. 1859. Polypen und Quallen von Santa Catharina: die Formwandlung der Liriope catharinensis n. sp. Arch. Naturg., 25(1): 310-321 (footnote by M. Schultze on p. 310).

1864. Für Darwin. Wilhelm Engelmann, Leipzig, 91 pp.

1871. Bruchstücke zur Naturgeschichte der Bopyriden. Jena Z. Med. Naturwiss., 6: 53-73, pls. 3-4.

Neave, S.A. (ed.). 1940. Nomenclator Zoologicus. Vol. IV. Q-Z and Supplement. Zoological Society of London, London, $758 \mathrm{pp}$.

Nielsen, S.-O. \& J.-O. Strömberg. 1965. A new parasite of Cirolana borealis Lilljeborg belonging to the Cryptoniscinae (Crustacea Epicaridea). Sarsia, 18: 37-62.

Nierstrasz, H.F. \& G.A. Brender à Brandis. 1923. Die Isopoden der Siboga-Expedition. II. Isopoda Genuina. I. Epicaridea. Siboga-Expeditic, 32b: 1-121, Taf. IV-IX.

— \& 1925. Bijdragen tot de Kemnis der Fauna van Curaçao. Resultaten eener reis van Dr. C.J. der Horst in 1920. Epicaridea. Bijdr. Dierk., 24: 1-8, 1 pl.

—_ \& 1929. Neue Epicaridea. Zool. Anz., 85(11/12); 295-302.

\& — - 1930a. Änderung des Namens der neuen Epicariden-Gattung Perezia in Perezina. Zool. Anz., 88(7/8): 223.

- \& 1930b. Three new genera and five new species of parasitic Crustacea. Proc. U. S. Nat. Mus., $77(9): 1-9$.

Pérez, G. 1920. Sur un Cryptoniscien nouveau, Enthylacus trivinctus n. g., n. sp., parasite intrapalléal 
d'une Sacculine; un cas de parasitisme au troisième degré. C. R. Hebd. Séances Acad. Sci. Paris, 171: $131-133$.

Rathke, H. 1843. Beiträge zur Fauna Norwegens. Verh. K. Leopold.-Carol. Akad. Naturf., 12: 1-264.

Sassaman, C. 1992. Description of the mature female and epicaridium larva of Cabirops montereyensis Sassaman from southern Galifornia (Crustacea: Isopoda: Cabiropidae). Proc. Biol. Soc. Wash., 105(2): 575-584.

Smith, G. 1906. Rhizocephala. Fauna und Flora des Golfes von Neapel und der angrenzenden Meeres-Abschnitte, Monogr. 29, viii +123 pp., pls. 1-8. R. Friedländer \& Sohn, Berlin.

Templeton, R. 1840. Description of a minute crustaccous animal, from the island of Mauritius (Zeuxo). Trans. Entomol. Soc. Lond., 2(4): 203-207.

von Martens, E. 1875. Crustacea: Zool. Rec., 10: 183-196.

Wägele, J. W. 1987. Evolution und phylogenetisches System der Isopoda. Stand der Forschung und neue Erkenntnisse. Habilitation dissertation, Universität Oldenburg, $399 \mathrm{pp}$.

- 1989 . Evolution und phylogenetisches System der Isopoda. Stand der Forschung und neue Erkenntnisse. Zoologica (Stuttgart), 140: 1-262.

Wimpenny, R.S. 1927. Observation sur Danalia ypsilon Smith. Bull. Inst. Océanogr. Monaco, 496: 1-8.

Zimmer, C. 1927. Ordnung der Crustacea: Isopoda=Asseln. In: Kükenthal, W. \& Krumbach, T. (eds.), Handbuch der Zoologie, Band 3, Lief. 6-7, pp. 697-766. Walter de Gruyter, Berlin. 